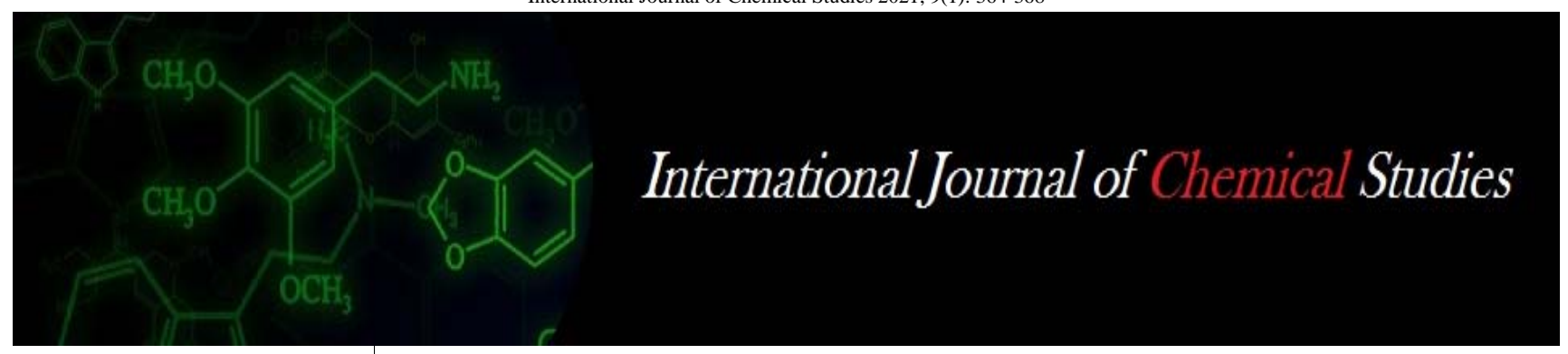

P-ISSN: 2349-8528 E-ISSN: 2321-4902 www.chemijournal.com IJCS 2021; 9(1): 364-368 (C) 2021 IJCS

Received: 15-11-2020

Accepted: 23-12-2020

Narendra Singh

Department of Tree

Improvement and Genetic

Resources, Dr. Yashwant Singh

Parmar University of

Horticulture and Forestry,

Nauni, Solan, Himachal

Pradesh, India

\section{Tara Gupta}

Department of Tree

Improvement and Genetic

Resources, Dr. Yashwant Singh

Parmar University of

Horticulture and Forestry,

Nauni, Solan, Himachal

Pradesh, India

Bhupender Dutt

Department of Tree

Improvement and Genetic

Resources, Dr. Yashwant Singh

Parmar University of

Horticulture and Forestry,

Nauni, Solan, Himachal

Pradesh, India
Corresponding Author:

Narendra Singh

Department of Tree

Improvement and Genetic

Resources, Dr. Yashwant Singh

Parmar University of

Horticulture and Forestry,

Nauni, Solan, Himachal

Pradesh, India

\section{Variation in physico chemical characteristics of Toona ciliata M. Roem provenances}

\author{
Narendra Singh, Tara Gupta and Bhupender Dutt
}

DOI: https://doi.org/10.22271/chemi.2021.v9.i1e.11256

\section{Abstract}

Toona ciliata M. Roem belongs to family Meliaceae is one of the best known Indian timber species, popularly known as Toon and Red cedar. The aim of the study was to determined physico chemical characters of wood of Toona ciliata collected from three states. The moisture and maximum moisture content (\%) and specific gravity were found to be significant variation in sapwood and heartwood of wood parameters. The variation in water and chemical (\%) and Alcohol benzene soluble extractives was found characteristics wood samples. Variation in holocellulose and lignin content (\%) was found significant variation in different provenances. The wood samples from Uttarakhand found better as per selected parameters in comparison to the chemical characters of wood from Himachal Pradesh and Uttar Pradesh.

Conclusion: During this study it was observed the variability in physico chemical characteristics. The two provenances viz Naini and Nauni have been measured percent of holocellulose (74.50) and lignin (28.5) respectively under sharp focus for utilization and deployment for future improvement programme.

Keywords: Specific gravity, wood sample, physico chemical relation, benzene, holocellulose moisture content per cent

\section{Introduction}

Toona ciliata M. Roem is one of the best known Indian timber species, popularly known as Toon and Red cedar. Investigation was carried out in three different provenances of India viz. Himachal Pradesh, Uttarakhand and Uttar Pradesh. The species of Toona's wood which is light, straight-grained, rather uneven and moderately hard with specific gravity of 0.57 (Troup, 1981) ${ }^{[20]}$. The other timber yielding species of the genus occurring in India are Toona febrifuga, T. microcarpa and Toona serrata. Meliaceae is a large family of tropical woody species, comprising of 50 genera with approx.575 species (Pennington and Styles, 1975; Mabberley et al., 1995; Chase et al., 1999) ${ }^{[5,12,15]}$ and further categorized into four subfamilies viz. Meliodeae (07 tribes, 35 genera) Swieteniodeae (03 tribes, 13 genera) and the monogeneric Quivisianthoideae and Capuronianthoideae, which contain a relatively wide range of floral, fruit and seed morphologies (Pennington and Styles, 1975) ${ }^{[15]}$. Toona ciliata is a large deciduous moderate light demanding tree with a spreading crown, commonly attaining a height of $20-30 \mathrm{~m}$ and a girth of $1.8-3.0 \mathrm{~m}$. In India, it is found throughout the sub-Himalayan tract, western-Himalaya and valleys of the outer Himalaya including Himachal Pradesh, Uttarakhand and Uttar Pradesh up to an elevation of 1600m amsl. The species also occurs in the plains of Madhya Pradesh, Tamil Nadu, Karnataka, eastern and western Ghats distributed up to elevation of $1200 \mathrm{~m}$ amsl (rarely $1300 \mathrm{~m}$ ) in western peninsula (Singh, 1982) ${ }^{\text {[12, 19] }}$. On moist localities such as ravines, stream banks or swamps (Troup, 1981) ${ }^{[20]}$. T. ciliata is mostly grown for its versatile timber, which is used for building houses and ships and for high-value goods such as furniture, musical instruments, carvings, and numerous other uses like dyes and tans from flowers and bark respectively (Lemmens, 2008) ${ }^{[10]}$. A more comprehensive research approach should aim to understand which factors limit tree growth, which tree species are more suitable to cope with limited resources, and which mechanisms allow them to adjust to changes in environmental conditions. In view of the increasing demand for the valuable timber produce by this species, along with other multipurpose uses like medicinal, fodder values and soil conservation in hilly terrains; there is a need to establish a provenances trial, in order to establish the identity of superior provenances across a vast geographical stretch. 


\section{Materials and Methods}

A field survey was carried in twelve provenances (Nauni, Hamirpur, Thakurdwara, Ghumarwin, Nurpur, Nainikhad, Una, Rajpur, Kathgodam, Naini, Nagina and Sarsawa) bearing Toona ciliata trees in the state of Himachal Pradesh for undertaking the present study. The Himachal Pradesh, Utterakhand and Uttar Pradesh collection was done from respectively seven, three and two. Core samples was collected with help of increment borer from different provenances Himachal Pradesh, Utterakhand and Uttar Pradesh. Core samples was dried in oven on $105{ }^{\circ} \mathrm{C}$ and then grinded with the help of grinder machine. Fresh weight of the wood samples was recorded just after their extraction from trees of different provenances. After initial weight on balance, the samples were oven dried at $102{ }^{\circ} \mathrm{C}$ till constant weight. Same wood samples which were dipped in water for maximum moisture content was used for determine specific gravity of toon wood from different sites of different provenances. After maximum saturation point with water treatment, samples were first dried in air and then dried at $105+2$ to constant weight. Cold water Two grams of oven dry wood meal was weighed and transferred into a conical flask containing $300 \mathrm{ml}$ of distilled water. Hot water Two grams of oven dry wood meal was taken in a flask having $100 \mathrm{mi}$ of double distilled water filtered with reflux condenser. Alcohol-benzene extractives two grams oven dry powdered wood sample was placed in a porous thimble (oven dried and weighed). The alcoholbenzene solubility was determined by calculating the loss in weight of the sample taken and expressed in percentage. Determination of Holocellulose two grams of oven dried sample pre-extracted with alcohol-benzene (1:2 v/v) was taken in a conical flask and $160 \mathrm{ml}$ of distilled water was added to it. Then contents were treated with 1.5 gram of Sodium chlorite and 10 drops of acetic acid at $70-80{ }^{\circ} \mathrm{C}$ on a water bath for one hour. Then contents were filtered through IG-2 crucible, washed with water and finally with acetone. The per cent holocellulose content was calculated on the basis of the oven dry weight. Lignin content: Two grams oven dry sample pre-extracted with alcohol-benzene (1:2 v/v) was treated with $15 \mathrm{ml}$ of 72 per cent sulphuric acid for 2 hours at 18-20 ${ }^{\circ} \mathrm{C}$ with constant. The contents were filtered, washed with hot distilled water and dried in an oven at $1052 \mathrm{c}$ till constant weight and expressed in percentage on oven dry weight basis.

\section{Result and Discussion}

Estimation of moisture content, maximum moisture content and specific gravity of both sapwood and heartwood

Table 1: Variation in fresh moisture content and maximum moisture content (\%) in sapwood and heartwood of different provenances Toona ciliata

\begin{tabular}{|c|c|c|c|c|c|}
\hline \multirow{2}{*}{ Sr. No. } & \multirow{2}{*}{ Provenances } & \multicolumn{2}{|c|}{ Sapwood } & \multicolumn{2}{c|}{ Heartwood } \\
\cline { 3 - 6 } & & Moisture content (\%) & Maximum moisture content (\%) & Moisture content (\%) & Maximum moisture content (\%) \\
\hline $\mathrm{P}_{1}$ & Nauni & 58.98 & 179.89 & 49.28 & 158.02 \\
\hline $\mathrm{P}_{2}$ & Hamirpur & 45.66 & 149.38 & 54.95 & 161.91 \\
\hline $\mathrm{P}_{3}$ & Thakurdwara & 40.69 & 167.27 & 41.42 & 127.65 \\
\hline $\mathrm{P}_{4}$ & Ghumarwin & 29.05 & 175.23 & 47.23 & 148.39 \\
\hline $\mathrm{P}_{5}$ & Nurpur & 52.33 & 168.39 & 44.15 & 135.40 \\
\hline $\mathrm{P}_{6}$ & Nainikhad & 56.08 & 148.31 & 54.28 & 138.23 \\
\hline $\mathrm{P}_{7}$ & Una & 34.98 & 164.22 & 42.83 & 167.40 \\
\hline $\mathrm{P}_{8}$ & Rajpur & 50.71 & 174.22 & 49.56 & 138.84 \\
\hline $\mathrm{P}_{9}$ & Kathgodam & 49.90 & 138.55 & 48.60 & 151.60 \\
\hline $\mathrm{P}_{10}$ & Naini & 33.97 & 144.23 & 47.97 & 156.29 \\
\hline $\mathrm{P}_{11}$ & Nagina & 44.74 & 154.46 & 42.05 & 168.22 \\
\hline $\mathrm{P}_{12}$ & Sarsawa & 40.13 & 146.30 & 41.28 & 119.27 \\
\hline & Mean & 44.77 & 159.20 & 48.71 & 147.60 \\
\hline & SE $(\mathrm{d})$ & 2.18 & 5.89 & 3.56 & 7.89 \\
\hline
\end{tabular}

The data on variation in moisture content (\%) and maximum moisture content (\%) for both sapwood and heartwood in toon wood samples from different provenances are presented in Table 1. The effect of provenances on these parameters was found to be significant. In case of sapwood, moisture content (\%) was found to be maximum in Nauni (58.98\%). Maximum moisture content (\%) was found to be highest in Nauni (179.89). The minimum value was recorded in Kathgodam (138.55\%). In case of heartwood, moisture content (\%) was found maximum in Hamirpur (54.95\%) and minimum was found in Sarsawa (41.28\%). Maximum moisture content (\%) was found to be highest in Nagina (168.22\%) and minimum was found in (127.65\%) provenances. The water in wood is held in cellular cavities and cell wall. The moisture content and maximum moisture content in living trees vary by species and also due to sapwood and heartwood content. In the present study the significant variation in maximum moisture content of different toon provenances have been recorded.
Wood moisture generally vary within stems, commonly peaking towards the outer edges in the redial direction and declining towards the heartwood, leading to different moisture contents between heartwood and heartwood and sapwood (Rackzkowaki et al., 2000; Spicer and Gartner 2001). The moisture content variables have shown significant variations among core samples collected from different populations of Dipterocarpus indicus (Nageeb et al. 2010) ${ }^{[14]}$. The similar results have been reported by EI Baha et al., (2002) ${ }^{\text {[3] in }}$ Leucaena leucocephala. Getahun et al. (2014) ${ }^{[8]}$ have found variation in initial moisture content within tree in Pinus Patula which showed decreasing trend from bottom to top of tree.

\section{b) Specific gravity of sapwood and heartwood}

The data pertaining to variation in specific gravity of sapwood and heartwood of different toon provenances are presented in Table 2. The specific gravity of sapwood was found to be maximum in Hamirpur (0.502). In case of heartwood, the 
specific gravity was recorded to be maximum in Rajpur (0.549) provenances, whereas the minimum value was recorded in Nagina $(0.385)$ provenances.

Table 2: Variation in specific gravity sapwood and heartwood of different provenances of Toona ciliata

\begin{tabular}{|c|c|c|c|}
\hline \multirow{2}{*}{ Sr. No. } & \multirow{2}{*}{ Provenances } & \multicolumn{2}{|c|}{ Specific gravity } \\
\cline { 3 - 4 } & & Sapwood & Heartwood \\
\hline $\mathrm{P}_{1}$ & Nauni & 0.453 & 0.495 \\
\hline $\mathrm{P}_{2}$ & Hamirpur & 0.442 & 0.439 \\
\hline $\mathrm{P}_{3}$ & Thakurdwara & 0.502 & 0.544 \\
\hline $\mathrm{P}_{4}$ & Ghumarwin & 0.449 & 0.477 \\
\hline $\mathrm{P}_{5}$ & Nurpur & 0.483 & 0.522 \\
\hline $\mathrm{P}_{6}$ & Nainikhad & 0.475 & 0.466 \\
\hline $\mathrm{P}_{7}$ & Una & 0.418 & 0.428 \\
\hline $\mathrm{P}_{8}$ & Rajpur & 0.477 & 0.549 \\
\hline $\mathrm{P}_{9}$ & Kathgodam & 0.455 & 0.543 \\
\hline $\mathrm{P}_{10}$ & Naini & 0.466 & 0.511 \\
\hline $\mathrm{P}_{11}$ & Nagina & 0.381 & 0.385 \\
\hline $\mathrm{P}_{12}$ & Sarsawa & 0.459 & 0.479 \\
\hline & Mean & 0.455 & 0.487 \\
\hline & SE $(\mathrm{d})$ & 0.006 & 0.005 \\
\hline & CD 0.05 & 0.013 & 0.011 \\
\hline
\end{tabular}

The most probable reason for this is stressed conditions and variable site factors. Similar findings have been reported by Kennedy and smith (1959) in Populus trichocarpa as the site changed from good to poor, the specific gravity has shown increase from 0.331 to 0.383 . Awang and Taylor (1993) ${ }^{[2]}$ have reported that values obtained for specific gravity at drier sites (0.6) were substantially higher than those at wetter sites (0.4) in Acacia mangium. Zobel and Van Buijtenen (1989) ${ }^{\text {[23] }}$ have also compared specific gravity in Sitka spruce of North and south provenances and found that faster growing more southerly Sitka spruce provenances produced denser timber compared to slow growing more northerly provenances. Cox et al., (2001) ${ }^{[6]}$ have reported that specific gravity is heritable and the differences between wood are due to the genetic make-up. They have found significant variations in the specific gravity of Shorea acuminata, S. ovalis, S. leprossula and Drybalanops aromatica. Similarly Martinez et al. (2009) ${ }^{[13]}$ have recorded that wood density was more significantly correlated with precipitation and aridity than temperature. As high of wood density is achieved though reductions in cell size and increase in the proportion of wall relative to lumen and density is independent of vessel traits. Nageeb et al. (2010) ${ }^{[14]}$ have shown significant variations in wood density of core samples collected from Dipterocarpus indicus of different populations. Igartual et al. (2003) have studies basic density at breast height of 35.-year -old Eucalyptus globulus for parameter prediction of the whole tree and Wahlgren and Fassnachat (1959) ${ }^{[21,22]}$ have suggested that increment cores extracted at breast height could be safely used to estimated whole -tree density.

Table 3: Variation in water and chemical soluble extractives (\%) of different toon provenances

\begin{tabular}{|c|c|c|c|c|}
\hline Sr. No. & Provenances & Cold water soluble extractives (\%) & Hot water soluble extractives (\%) & Alcohol-benzene soluble extractive (\%) \\
\hline $\mathrm{P}_{1}$ & Nauni & 5.63 & 9.50 & 8.40 \\
\hline $\mathrm{P}_{2}$ & Hamirpur & 4.90 & 9.75 & 7.57 \\
\hline $\mathrm{P}_{3}$ & Thakurdwara & 6.20 & 8.31 & 8.37 \\
\hline $\mathrm{P}_{4}$ & Ghumarwin & 5.84 & 7.61 & 6.27 \\
\hline $\mathrm{P}_{5}$ & Nurpur & 5.10 & 8.32 & 6.10 \\
\hline $\mathrm{P}_{6}$ & Nainikhad & 4.05 & 9.57 & 8.13 \\
\hline $\mathrm{P}_{7}$ & Una & 6.87 & 8.57 & 7.63 \\
\hline $\mathrm{P}_{8}$ & Rajpur & 4.19 & 7.34 & 6.83 \\
\hline $\mathrm{P}_{9}$ & Kathgodam & 4.72 & 9.53 & 7.13 \\
\hline $\mathrm{P}_{10}$ & Naini & 5.08 & 8.12 & 6.33 \\
\hline $\mathrm{P}_{11}$ & Nagina & 6.64 & 9.31 & 9.06 \\
\hline $\mathrm{P}_{12}$ & Sarsawa & 6.43 & 7.53 & 7.44 \\
\hline & Mean & 4.45 & 8.59 & 1.09 \\
\hline & SE $(\mathrm{d})$ & 1.95 & 1.81 & \\
\hline & CD 0.05 & 1.19 & 1.09 & 0.89 \\
\hline
\end{tabular}

\section{Chemical characteristics of wood}

\section{Water and chemical soluble extractives (\%)}

The data on variation in water and chemical soluble extractives of toon wood sample from different provenances are presented in 4. Among the different provenances, the maximum cold water soluble extractives per cent was found in Una (6.87\%), whereas, the minimum value was recorded in the Nainikhad (4.05\%) provenances. Maximum hot water soluble extractives per cent were recorded in Hamirpur (9.75\%). The minimum value was found (7.34\%) provenances. Maximum alcohol - benzene soluble extractive per cent was found in Sarsawa (9.06\%), whereas minimum was found Nurpur (6.10\%) Extractive contents consist of lipids (terpenoide, fat, wax, and fatacides) and phenolics, (single phenolics, stilbenel, lignane, flavonoide, tannin). The most amounts of ingredients can be found in core wood, wood rays, root wood, branch formation and at the bark. The above mentioned ingredients define wood colour, smell and durability as well as quality of pulping and drying and also the gluing properties (Lange and Schwager 1997). Pari et al.
(1997) have studied nine Indonesian species and found solubility in cold water, hot water and alcohol - benzene (1:2) which ranged from 4.33 to 7.41 per cent, 4.67 to 9.47 per cent and 1.99 to 9.21 per cent, respectively. The difference in solubility is due to hydrolysis and corresponding increase in solubility of wood substances during the boiling with water. The content, type and position of extractives affect the strength properties of wood (Narayanamurti and Verma, 1964). Water solubility of wood represents the low molecular weight compounds and polysaccharides. Hot water soluble extractives are more than cold water due to the reason that hot - water extraction eliminates greater quantities of materials and extracts some inorganic extractive (Shebani et al. 2008) ${ }^{[18]}$. Sodium hydroxide solubility shows the extent of fungal decay in wood. As fungal decay causes increase in sodium hydroxide solubility. Alcohol -benzene solubility of wood is an important character represent extractive present in wood which affect the quality of pulp, Pinus oocarpa (Morais et al. 2005). 
Table 4: Variation in Holocellulose and lignin content \% of different toon provenances

\begin{tabular}{|c|c|c|c|}
\hline Sr. No. & Provenances & Holocellulose (\%) & Lignin (\%) \\
\hline $\mathrm{P}_{1}$ & Nauni & 65.10 & 28.50 \\
\hline $\mathrm{P}_{2}$ & Hamirpur & 70.47 & 16.83 \\
\hline $\mathrm{P}_{3}$ & Thakurdwara & 70.13 & 28.33 \\
\hline $\mathrm{P}_{4}$ & Ghumarwin & 69.70 & 22.33 \\
\hline $\mathrm{P}_{5}$ & Nurpur & 69.67 & 20.33 \\
\hline $\mathrm{P}_{6}$ & Nainikhad & 72.00 & 22.00 \\
\hline $\mathrm{P}_{7}$ & Una & 70.53 & 24.00 \\
\hline $\mathrm{P}_{8}$ & Rajpur & 71.33 & 20.17 \\
\hline $\mathrm{P}_{9}$ & Kathgodam & 72.00 & 22.00 \\
\hline $\mathrm{P}_{10}$ & Naini & 74.50 & 21.83 \\
\hline $\mathrm{P}_{11}$ & Nagina & 70.67 & 19.33 \\
\hline $\mathrm{P}_{12}$ & Sarsawa & 68.17 & 25.67 \\
\hline & Mean & 70.36 & 22.61 \\
\hline & SE $(\mathrm{d})$ & 1.77 & 0.74 \\
\hline & CD 0.05 & 3.67 & 1.53 \\
\hline
\end{tabular}

The data represent in Table 4, revealed significant variations in Holocellulose and lignin per cent of different toon provenances. Among all provenances, Holocellulose per cent was found to be maximum in Naini (74.50\%) whereas, minimum was found in Nauni $(65.10 \%)$ provenances. The lignin per cent was found to be maximum in Nauni (28.50\%) whereas, the minimum value was recorded in Hamirpur (16.83\%) provenances. Holocellulose and hemicellulose together described as Holocellulose is used to denote the polysaccharides in wood. The Holocellulose content is a quantitative indication of fibrous raw material influencing consideration of its suitability for pulp. Whereas, lignin is a phenolic substance consisting of an irregular array of variously bonded hydroxyl-and methoxy-substituted phenylpropane units, which is distributed throughout the secondary cell wall with highest concentration in middle lamella and is responsible for providing stiffness to the cell wall. It is also seves to bond individual cells together in the middle lamella region (Alen, 2000) ${ }^{[1]}$. Photographs of Holocellulose and lignin after extraction are shown on plate -6. Alton et al. (1990) have reported that sapwood contained more holocellulose than heartwood. Among different provenances, significant variations have been noticed where, holocellulose ranged from 67.05-73.82 per cent and lignin content ranged from 21.03-25.95 percent. The results are in conformity with studies of Beleam and Harkin (1975) ${ }^{[4]}$ in Eucalyptus hybrid, Pari et al. (1997) in nine Indonesia species, Kumar (2000) ${ }^{[7,9]}$ in Dalbergia sissoo, Kumar et al. (2005) ${ }^{\text {7, 9] }}$ in Dalbergia sissoo, Fakharian et al. (2005) in Alnus glutinous and Lopez et al. (2008) in Leucaena leucocephala. Kumar et al. (2005) ${ }^{[7,}$

${ }^{9]}$ have estimated lignin content and holocellulose content of Dalbergia sissoo ranged from 23.90 - 30.50 per cent and 66.00 -76.55 per cent, respectively. Kaushal et al. (2012) have estimated lignin content of 21.45 per cent in Toona ciliata wood.

\section{Conclusion}

During this study it was observed the variability in physico chemical characteristics different provenances. Significant differences among provenances were detected of physico chemical characters such as moisture and maximum moisture content and specific gravity of sapwood and heartwood and others per cent of water and chemical soluble extractives (\%) and Holocellulose and lignin content (\%). The two provenances viz Naini and Nauni have been measured percent of holocellulose and lignin respectively under sharp focus for utilization and deployment for future improvement programme.

\section{Acknowledgements}

We thankful to University Grants Commission (UGC), New Delhi, and Government of India for financial support.

\section{References}

1. Alen R. Structure and Chemical composition of wood. In: Stenius P (ed) forest product chemistry. Jyvaskyla, Finland 2000; 2:11-57.

2. Alton GC, Wae J and Koch P. 1990. Chemical variation in lodge pine with sapwood heartwood, stem height and variety. Wood and Fiber Science 22:22-30.

3. Awang K, Taylor D. Acacia mangium-Growing and Utilization. Winrock International \& FAO. Bangkok, Thailand 1993, P267.

4. Baha AM. Biomass yield, chemical analysis, specific gravity and fiber length of Leucaena leucoephala trees planted in sandy soil at different ages and spacings. Alexandria Journal of Agricultural Research 2002;4:7-16.

5. Beleam RD, Harkin MJ. Lignin of hardwood growing on Southern pine Site. Wood Sciences 1975;8:122-129.

6. Chase MW, Morton CM, Kallunki JA. Phylogenetic relationship of Rutaceae: a cladistics analysis of the subfamilies using evidiences from rbcL and atpB sequences variation. American journal of Botany 1999;86:1191-1199.

7. Cox MC, Elouard CS, Rafedah AK, Roszaini K. Growth and wood quality of four plantation Dipterocarpus species from Malaysia. Proceeding of $6^{\text {th }}$ Round Table Conferences on Dipterocarpus, February 8-12 Banglore, India 2001.

8. Fakhrian A, Hosseinzadeh A and Golbabaei F. 2005. Ditermination of practical properties of Alnus glutinosa grown at short rotation period in paper making. Iranian Journal of wood and paper Sciences Research 20:65-92.

9. Getahun Z, Poddar P, Sahu O. The influences of physical and mechanical properties on quality of wood produced from Pinus patula Tree Grown at Arsi Forest. Advanced Reasearch Journal of plant and animal sciences 2014;2:32-41.

10. Igartual DV, Monteoliva SE, Monterubbianesi MG and Villegas MS. 2003. Basic density and fiber length at breast height of Eucalyptus globulus for Parameter prediction of the whole tree. Journal of international Association wood Anatomy 24:173184.

11. Kaushal R, Sharma N and Tandon D. 2012. Cellulose and xylanase production by coculture of Aspergillus nuger and Fusarium oxysporum utilizing forest waste. Turkish Journal of Biochemistry 37: 35-41.

12. Kennedy RW and Smith JH. 1959. The effect of some genetic and environmental factors on wood quality in popular. Pulp and Paper Magazine of Canada 60:35-36.

13. Kumar R, Sharma KR and Gupta LM. 2005. Variation in Physio-chemical of wood candidate plus tree of Shisham (Dalbergia sissoo Roxb.) Indian forester 131:1012-1023.

14. Kumar R. Evaluation of candidate plus trees of Dalbergia sissoo Roxb, for physico-chemical characeteristics of wood. M.sc. thesis. Department of Forest products. Dr. YS Parmar University of Horticulture and Forestry, Nauni, Solan (H.P.) 2000, P64.

15. Lange W and Schwager C. 1997. Akzessories Bestandteile dauerhafter holozarten and nicht verholzter pflanzen mit resitenzwirksamer Aktivitat Eine Litraturstudie. Arbeistberich der BFH. PP. 81-434.

16. Lemmens RHMJ. Toona ciliata Roem. Plant resources of tropical Africa 2008;7:557-559.

17. Lopez F, Garcia MM, Yanez R, Tapias R, Fernandez M, Diaz MJ. Leucaena species Valoration for biomass and paper production in 1 and 2 year harvest. Bioresource Technology 2008;99:4846-4853. 
18. Mabberley DJ, Pannell CM, Singh AM. Meliaceae. Flora Malesiana Series 1995;2:1-407.

19. Martinez CHI, Jones CS, Espino S, Schenk HJ. Wood anatomy and wood density in shrubs: responses to varying aridity along transcontinental transects. American Journal of Botany 2009;96:1388-1398.

20. Morais S, Nascimento EA and Melo DC. 2005. Chemical analysis of Pinus oocarpa wood part -1 quantisation of macromolecular components and volatile extractives, Revista Arvore 29:461-470.

21. Nageeb A, Sagheer A, Devi Prasad AG. Variation in wood specific gravity, density and moisture content of Dipterocarpus indicus (Bedd). Among different populations in western Ghasts of Karnataka, India. Internatinal Journal of Applied Agricultural Research 2010;5:583-599.

22. Narayanamurti D and Varma GM. 1964. Role of wood extractives in the rheological properties of wood. Holzforsch $U$. Holzeurt, Wien 16:51-55.

23. Pari G, Setiawana D and Saepuloh. 1997. Chemical analysis of nine wood species from Iran Java. Buletin Penelittian Hasil Hutan 15:87-93.

24. Pennington TD, Styles BT. A generic monograph of the Meliaceae. Blumea 1975;22:419-540.

25. Rackzowaki J, Olek W, Guzenda R. Moisture evaporation rates from sapwood and heartwood sample of Douglass-fir (Pseudotsuga menziesii) green wood. Holz als Roh - und Werkstoff 2000;58:247-252.

26. Shebani AN, Van Reenen AJ, Meincken M. The effected of wood extractives on the thermal stability of different wood species. Thermochemica Acta 2008;47:43-50.

27. Singh RV. Fodder trees of India. Oxford and IBH publishing company, New Delhi, India 1982, P663.

28. Spicer R and Garner BL. 2001. The effects of chembial age and position within the stem on specific conductivity in Douglas fir (Psedotsuga menzeisii) sapwood. Trees 15:222-229.

29. Troup RS. The Silviculture of Indian Trees. The Book 1981;11:88-196.

30. Wahlgren HE, Fassnacht DL. Estimating tree specific gravity from a single increment core.USDA, New York, USA 1959, P26.

31. Zobel BJ, Van Buijtenen JP. Wood variation, its causes and control. Springer, Berlin, Heidelberg, New York 1989, P363. 